\title{
Pemanfaatan Media Sosial Sebagai Sarana Outreach Wanita Pekerja Seks oleh Petugas Penjangkau Lapangan
}

\author{
Asep Rahman ${ }^{\text {* }}$, Gustafiano Setyadharmaputra Ruindungan ${ }^{2}$ \\ ${ }^{1}$ Fakultas Kesehatan Masyarakat Universitas Sam Ratulangi Manado \\ ${ }^{2}$ Fakultas Teknik Universitas Sam Ratulangi Manado \\ "Penulis Korespondensi. Email: aseprahman@ unsrat.ac.id
}

\begin{abstract}
ABSTRAK
Sejak ditemukannya pertama kali kasus HIV/AIDS di Sulawesi Utara, pada tahun 1997, peningkatan kasus senantiasa terjadi hingga saat ini. Penyebaran HIV/AIDS dapat dihindari dengan proses edukasi yang berkelanjutan, terutama pada populasi kunci seperti pekerja seks. Pemanfatan teknologi khususnya media sosial dapat menjadi sarana untuk memudahkan proses edukasi kepada populasi kunci. LKKNU Sulawasi Utara sebagai implementing unit dari SSR Yayasan Kerti Praja yang mendapatkan pendanaan Global Fund untuk penanggulangan HIV/AIDS melalui upaya penjangkuan berupa edukasi kesehatan dan perujukan ke layanan kesehatan. Pada kajian ini dimana merupakan hasil dari kegiatan pengabdian masyarakat yang dilakukan oleh penulis untuk mendapatkan gambaran tentang proses-proses edukasi oleh petugas lapangan bagi pekerja seks di Kota Manado. Dalam kajian ini diperoleh bahwa pemanfaatan media sosial sebagai sarana penjangkuan telah digunakan, namun butuh penguatan agar efektivitas pemanfaatannya maksimal. Selain itu penguatan kapasitas petugas lapangan akan pemanfaatan media sosial juga sangat perlu agar mampu menjangkau populasi kunci yang cenderung tertutup.
\end{abstract}

Kata Kunci: media sosial; pekerja seks; HIV/AIDS

\begin{abstract}
Since the discovery of HIV / AIDS love for the first time in North Sulawesi, in 1997, the increase of cases has continued until today. The spread of HIV / AIDS can be avoided by educational, especially for the key populations such as sex workers. The use of technology, especially social media, can be a means to facilitate the education process. LKKNU North Sulawesi as the implementing unit of the SSR Kerti Praja Foundation which received Global Fund funding for HIV / AIDS prevention through outreach efforts in the form of health education and referral to health services. In this study, which is the result of community service activities carried out by the author to get an overview of the educational processes by field officers for sex workers in Manado City. In this study, it was found that the use of social media as an outreach tool has been used, but it needs strengthening so that its effectiveness can be maximized. In addition, strengthening the capacity of field officers in the use of social media is also very necessary in order to be able to reach key populations who tend to be closed.
\end{abstract}

Keywords: social media; sex worker; HIV/AIDS 


\section{PENDAHULUAN}

\section{Analisis Situasi}

Human Immunodeficiency Virus (HIV) merupakan problem kesehatan masyarakat di Indonesia yang belum selesai tertangani selain masalah kesehatan lainnya. Tercatat perkembangan HIV di Indonesia merupakan yang tercepat di kawasan Asia Pasifik. Dalam kajian epidemi, pola sebaran HIV terkonsentrasi pada empat populasi kunci yaitu penggu-na narkoba suntik, transgender, pekerja seks perempuan, dan laki-laki yang berhubungan seks dengan laki-laki (UNAIDS, 2018).

Perkembangan HIV/AIDS nyatanya semakin lama semakin mengkhawatirkan baik dari sisi kuantitatif maupun kualitatif. Kini Indonesia menjadi ke lima di Asia dengan risiko HIV/AIDS yang tinggi. Uniknya jumlah kasus HIV\&AIDS yang tercatat sebenarnya masih jauh lebih kecil dari prevalensi fakta di lapangan, sehingga kita menyebutnya sebagai fenomena Gunung Es (Kemenkes RI, 2011).

Saat ini media komunikasi menjadi sangat diperlukan pada semua aspek kegiatan manusia. Sebab dengan komunikasi, kita dapat mengekspresikan gagasan, perasaan, harapan dan kesan kepada sesama atau sebaliknya. Komunikasi bukan saja mendorong perkembangan kemanusiaan lebih baik, namun juga mampu menciptakan hubungan sosial yang sangat diperlukan dalam kelompok masyarakat. Komunikasilah yang memungkinkan terjadinya kerjasama sosial di masyarakat, terciptanya kesepakatan-kesepakatan penting dan lain sebagainya.

Perkembangan teknologi yang kian pesat saat ini tentu saja menuntut kita agar tanggap dengan segala sesuatu yang berhubungan dengan teknologi canggih tersebut sebagai alat untuk berkomunikasi dan transfer pengetahuan. Kita tahu bahwa teknologi akan selalu berkembang dengan cepat dan menimbulkan berbagai pengaruh bagi kehidupan manusia.

Media sosial merupakan salah satu hasil dari perkembangan teknologi yang paling mutakhir dan disukai oleh banyak orang. Pemanfaatan media sosialpun beragam mulai dari sekedar mencari teman, reuni, mencari hobi, bahkan memanfaatkan untuk memasarkan produk usaha. Namun potensi pemanfaatan media sosial sebagai sarana eduksi sangatlah besar.

Petugas lapangan LKKNU Sulawesi Utara belum secara maksimal menggunakan media sosial sebagai sarana kampanye digital terkait HIV/AIDS. Mengembangkan pandangan Notoatmodjo (2003) yang mengutip Teori Lawrance Green bahwa tidak maksimalnya sebuah model intervensi dalam kampanye digital disebabkan oleh (1) faktor predisposisi meliputi pengetahuan dan sikap dari petugas lapangan, (2) faktor pemungkin meliputi ketersediaan fasilitas, sarana dan pelatihan, serta (3) faktor penguat meliputi regulasi, model dan pengawasan oleh lembaga.

\section{Tujuan dan Manfaat Kegiatan}

Tujuan dari kegiatan ini yakni meningkatkan pengetahuan tentang metode pengjangkauan digital dan faktor pemungkin yakni memfasilitasi pembuatan akun media sosial atau sarana kampanye digital, serta faktor pemungkin yakni pembuatan model kampanye digital yang tepat sasaran. Ketiga intervensi ini bertujuan dapat terlaksananya kampanye digital melalui media sosial oleh petugas penjangkau lapangan LKKNU Sulawesi Utara

\section{METODE PELAKSANAAN Sasaran Kegiatan}

Sasaran kegiatan ini adalah petugas penjangkau lapangan berjumlah 5 orang.

\section{Lokasi Kegiatan}

Kegiatan dilakukan secara face-to-face dengan mematuhi protokol kesehatan di Sekteriat LKKNU Sulawesi Utara dan kegiatan online melalui fasilitas zoom meeting dan Whatsapp Video.

\section{Metode Pelaksanaan}

Kegiatan dilakukan dengan melakukan ceramah/kuliah tentang: (1) pentingnya pemanfaatan media sosial sebagai sarana edukasi; (2) jenis-jenis media sosial potensial yang dapat digunakan sebagai sarana edukasi; (3) teknik-teknik pemanfaatan media sosial dalam kegiatan outreach seorang petugas lapangan 


\section{HASIL DAN PEMBAHASAN \\ Hasil}

Responden dalam kegiatan ini sebanyak lima orang semua jenis kelamin perempuan. Dalam proses pendalaman isu, peneliti melakukan wawancara mendalam. Berikut ini beberapa isu yang berkembang

Semua petugas lapangan mempunyai media sosial yang sudah digunakan oleh petugas lapangan. "FB dan WA torang so biasa gunakan." ujar responden. Selain itu beberapa aplikasi seperti Michat juga digunakan sebagai sarana penjangkuan. "Kalau michat banyakan nyanda betul", kata respon. Aplikasi Michat digunakan namun bukan sebagai aplikasi utama penjangkuan karena beberapa pengguna aplikasi ini cenderung menggunakan akun palsu.

Fakatanya penggunaan media sosial masih pada seputaran teman-teman dari petugas lapangan. Karena nomor HP yang terhubung ke aplikasi Whatsapps lebih mudah dilakukan. Serta beberapa mendapatkan nomor Whatsapps setelah mendapatkan kontak dari yang bersangkutan dan merasa nyaman untuk berkomunikasi. Penjangkuan melalui Facebook juga cenderung menyasar teman-teman yang sudah dikenal sebelumnya.

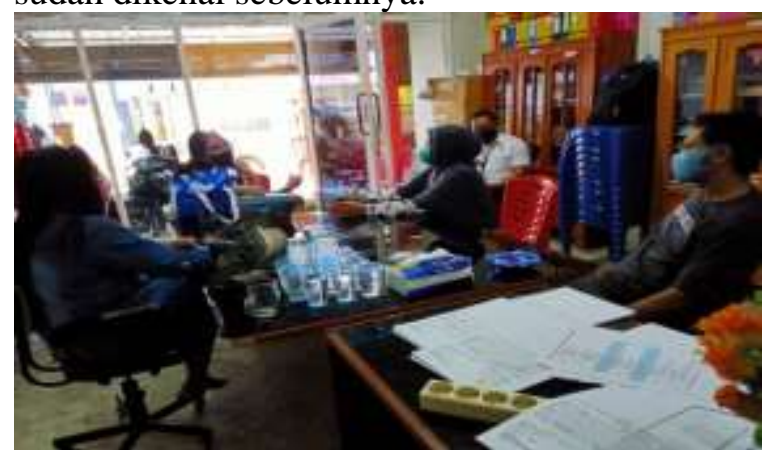

Gambar 1. Suasana pelatihan penggunaan media sosial di LKKNU Sulawesi

Banyaknya akun palsu pada media sosial juga menyulitkan petugas lapangan untuk memfollow-up jangkuan ke layanan kesehatan. "Bukan dorang itu akun, kadang hanya pake foto-foto orang laeng", tutur responden. Akun palsu ini biasanya digunakan oleh pekerja seks untuk melindungi diri dari penipuan, "dorang jaga-jaga kata, nanti ketemu baru buka identitas", tambah responden.

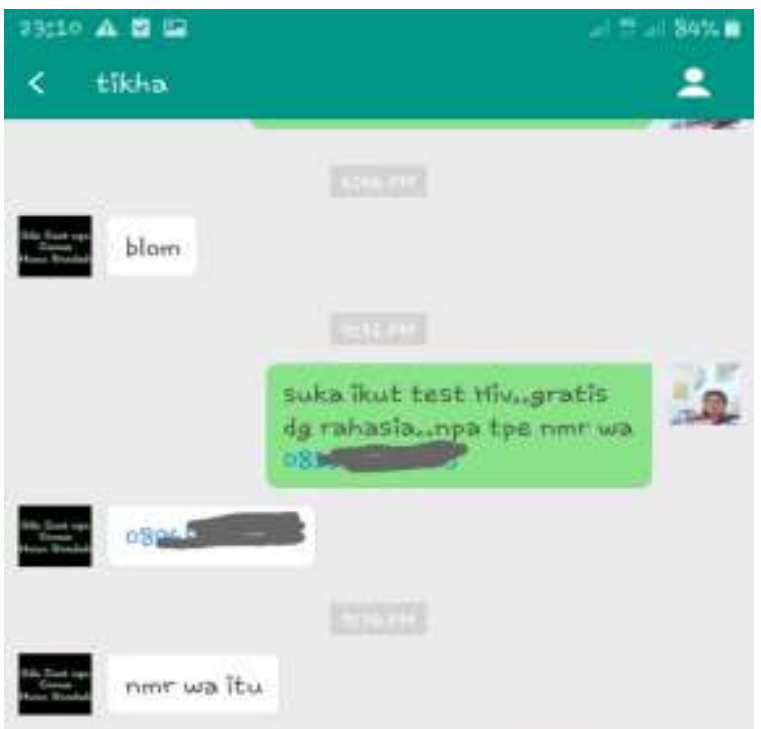

Gambar 2. Pemanfaatan aplikasi Michat sebagai sarana outreach oleh petugas lapangan

Kepercayaan pekerja seks terhadap akun penjangkau juga beragam. "Kita so pake foto asli dan di diprofil so jelaskan bahwa kita petugas penjangkau," tutur responden. Walaupun sudah menggunakan akun asli, populasi kunci sangat minim interaksi. "Mungkin sto karena torang sesama parangpuang, kalau kita dusu dapa blokir leh," tambah responden.

\section{Pembahasan}

1. Efektivitas media sosial

Media sosial sebagai alat komunikasi antar manusia dimana mereka dapat menciptakan, berbagi, dan bertukar informasi dalam jaringan internet (networks). Selain itu, media sosial juga dimaknai sebagai bentuk komunikasi yang bermediasikan komputerisasi, seperti email dan percakapan online yang memungkinkan pengguna untuk bertukar konten melalui internet (Collins, 2014). Dengan demikian, pemanfaatan media sosial sebagai sarana edukasi melalui konten-konten pembelajaran sangatlah tepat.

Efektivitas media sosial sebagai sarana promosi kesehatan cukup baik. Selain itu kemudahan akses informasi menggunakan media sosial dapaat menjadi kelebihan dari pemanfaatan media sosial. Media sosial merupakan alat ampuh untuk pendidikan dan advokasi mengenai masalah kesehatan 
masyarakat (Farnan dkk., 2013). Meluasnya penggunaan media sosial juga dapat mempengaruhi perilaku masyarakat dan tujuan kesehatan melalui penguatan sosial, karena manusia adalah spesies yang sangat sosial dan sering dipengaruhi oleh rekan mereka (Georgedkk., 2013).

2. Tantangan pemanfaatan media sosial

Berbeda dengan penjangkuan face-toface, penjangkuan dengan menggunakan media sosial sosial lebih sulit, karena minimnya kepercayaan penerima informasi. Seringkali pekerja seks yang menggunakan media tidak terbuka akan identitas dan minim interaksi, justru dominan sebagai silent reader. Namun bukan berarti informasi yang disampaikan tidak tepat pada pekerja seks. Biasanya dikemudian hari mereka menghubungi petugas lapangan bahwa pernah mendapatkan informasi sebelumnya melalui media sosial.

3. Skill penggunaan

Konten edukasi menjadi hal krusial karena petugas lapangan sering kali hanya menggunakan konten yang sudah ada di dunia maya. Perlu olah kembali seperti penggunaan bahasa lokal dan ajakan lansung ke layanan kesehatan di Kota Manado. Skill edukasi berupa literasi digital perlu juga dimiliki oleh petugas lapangan.

Skill penggunaan media sosial dapat meningkatkan kelebihan media sosial yang memiliki aksesibilitas yang tinggi. Sebab penerima informasi sesui dengan ketersediaan waktu dan tempat, responden dapat mengakses berulangkali informasi tersebut kapanpun dan dimanapun ia berada (Amichai-Hamburger, 2013).

\section{KESIMPULAN DAN SARAN Kesimpulan}

Pemanfaatan media sosial tidak selamanya berasal dari ketidak tahuan dari petugas lapangan. Beberapa petugas lapangan nyatanya tengah menggunakan aplikasi online seperti melalui Whataspp, Facebook Mesengger, Michat, namun tingkat respon dari target masih rendah. Hal ini disebabkan masih tertutupnya pekerja seks untuk membuka identitasnya melalui jejaring sosial. Namun demikian bukan berarti penggunaan media sosial bukanlah sarana yang tepat.

\section{Saran}

Melalui kajian ini dapat disarankan bahwa petugas lapangan perlu penguatan secara spesifik seperti jenis konten, time management untuk penggunaan media sosial serta pentingnya literasi digital. Penggunaan media sosial yang hanya pada momen tertentu tidak efektif jika tidak lakukan secara berkelanjutan.

\section{UCAPAN TERIMAKASIH}

Terima kasih yang mendalam kepada LKKNU Sulawesi Utara sebab kajian ini dapat terlaksana dengan baik karena kerjasama yang baik, khususnya petugas lapangan yang telah bersedia untuk berbagi informasi proses penjangkuan kepada populasi kunci yakni pekerja seks. Tim pelaksana juga mengucapkan terima kasih kepada Universitas Sam Ratulangi yang telah memberikan pendanaan dalam rangkain kegiatan pengabdian masyarakat ini.

\section{DAFTAR PUSTAKA}

Benotsch EG, Kalichman SC, Cage M. 2002. Men who have met sex partners via the Internet: prevalence, predictors, and implications for HIV pre-vention. Archives of Sexual Behavior.

Chambers, Robert. 1996. PRA (Participatory Rural Appraisal) Memahami Desa Secara. Partisipatif. Yogyakarta: Penerbit Kanisuis

Conn C, Nayar S, Lubis D, Maibvisira C, Modderman K. 2017. Vulnerable Youth as Prosumers in HIV Prevention: Studies Using Participatory Action Research. JMIR Public Health Surveill.

George, D. R., Rovniak, L. S.dan Kraschnewski, J. L. (2013). Dangers and opportunities for social media in medicine.Clin Obstet Gynecol, 56(3), hal. $453-462$ 
Guadamuz TE, Cheung DH, Wei C, Koe S, Lim SH. 2015. Young, online and in the dark: Scaling Up HIV testing among MSM in ASEAN. PLoS ONE.

Farnan, J. M. et al.(2013).Online Medical Professionalism : Patient and Public Relationships : Policy Statement From the American College of Physicians and the Federation of State Medical Boards.Annals of Internal Medicine, 158(8), hal. 620-627.

Kemenkes RI. 2011. Pedoman Nasional Manajemen Program HIV dan AIDS. Jakarta : Direktorat Jenderal Pengendalian Penyakit dan Penyehatan Lingkungan.

Kominfo.(2014).Riset Kominfo dan UNICEF Mengenai Perilaku Anak dan Remaja Dalam Menggunakan Internet. Tersedia di https://kominfo.go.id (Diakses: 1 Februari 2018).

Kurniawati, Herlin Fitriani. Gambaran Penggunaan Internet Dalam Pencarian Informasi Tentang Hiv Dan Aids Pada Remaja. DOI : 10.26714/jk.8.1.2019.2737

Nugrohoi, C. V. (2014). Pengaruh Pemberian Materi Kesehatan Reproduksi Melalui Grup Facebook Terhadap Pengetahuan Remaja.Jurnal Promkes, 2(2), hal.128-139.

Rochdyanto, Saiful. 2000. Langkah-langkah Pelaksanaan Metode PRA. Makalah ToT PKPI. Yogyakarta

Rosenberger JG, Reece M, Novak D, Mayer K. 2011. The Internet as a valuable tool for promoting a new framework for sexual health among gay men and other men who have sex with men. AIDS Behaviour.
UNAIDS. 2018. UNAIDS data 2018. Switzerland: UNAIDS

Wei C, Lim SH, Guadamuz TE, Koe S. Virtual versus physical spaces: Which facilitates greater hiv risk taking among men who have sex with men in east and South East Asia? AIDS and Behavior . 2014;18(8):1428-35. 